\title{
Bid Evaluation Model of Construction Projects Based on Information Entropy and Value Engineering PENG SOTHEA, BAO XUE YING
}

\author{
(College of Civil Engineering, Lanzhou Jiaotong University, Lanzhou Gansu, China) \\ sotheapeng@gmail.com; sotheapeng168@yahoo.com
}

\begin{abstract}
Keywords: value engineering; evaluation; information entropy
Abstract: At present, it has many bid evaluation of construction units that mainly rely on an expert scoring method to determine the successful bidder. That is the reason why the evaluation process has a great subjective. Thus this paper wants to propose a comprehensive evaluation model by combining entropy method and value engineering evaluation method, which can avoid the subjective evaluation process that mainly relies on the expert scoring method, to do an evaluation. The evaluation process is more rational and its result is more impartial; moreover, every tender unit is believable.
\end{abstract}

\section{Introduction}

In the process of project evaluation, it is necessary to set up the analytic index factors. In the purpose to conducive a fairly environmental competition, the setting up of scientific and reasonable evaluation method is required to apply for finding the final selection of the best contractor. At the present in the construction market, the technology is the main part that still focuses on the expert to give the score, which its evaluation result have a lot of subjectivity. For like example, Professor Wang Zhuo fu proposed the experts to give the score by using of information entropy weighted method to evaluate the project ${ }^{[1]}$, but this method is still based on the basis of an expert to give the score, so it did not completely shake off the subjectivity. Besides this, Professor Wang En-mao also proposed the value engineering method for evaluating the project ${ }^{[2]}$, but the every index weight was relied on the experts to determine. Then Zhu Sai jing proposed information entropy and the idea of gray correlation analysis to evaluate the project ${ }^{[3]}$. This paper, using the combination of entropy weight method and value engineering method, proposes a method to evaluate the project, which can avoid the subjectivity of evaluation result, and its evaluation process is very simple and practicable.

Since the 18th China National Congress, the Chinese government has especially emphasized in environmental protection. Although the China has an environmental assessment department to inspect the project, but it has an only qualitative inspection; it has no quantitative evaluation because the construction unit does not pay enough attention. Thus the evaluation of indicators from this article joins the environmental protection measures, and its evaluation result is more reasonable.

\section{Using information entropy to determine the weight of the model set up}

Entropy was originally a thermodynamical concept, which was firstly introduced by C.E Shannon into the theory of information, so it was called information entropy. The measuring of disorder system level is used in information entropy method, which tolerances the known data including the effective information, to determine the weight. If the entropy of an indicator value is smaller, the variation degree of the value index is bigger, so the providing information is greater, and the indicator in the comprehensive evaluation is greater effective, which lead the weight of the 
index is bigger too; otherwise, the weight of indicator is smaller ${ }^{[4]}$. When the value index of each object being evaluated is exactly the same, the entropy of information is maximized, so it means that the indicator cannot provide valid information for the evaluation and can be removed from the evaluation index system. Therefore, according to the degree of variation of each value index, the entropy of each index can be calculated by the entropy method, and all the indexes are weighted by the entropy of each index so that the object evaluation result is obtained.

The steps to determine the weight of an indicator using information entropy are as following:

1. With $m$ bidding units, $n$ evaluation indicators, the formation of index data matrix $\mathrm{X}=\left(x_{i j}\right)_{m \times n}$. which $x_{i j}$ represents the $i$-th bid unit for the $j$-index data.

2. Standardize to handle data

Different indicators have different dimensions, and it cannot compare, so we need to make indicator value be the standard value. Thus in order to make all indicators be the main direction, and eliminate the impact of the dimension, the ultimate data are converted into data on the range which interval between $[0,1]$. There are many ways to standardize data. The common method used in entropy weight is the variation method, so this paper chooses this method to use in.

For the main direction index, the formula is:

$$
\mathrm{y}_{i j}=\frac{x_{i j}-\min _{1 \mathrm{gimm}} x_{i j}}{\max _{1 \leq i \leq m} x_{i j}-\min _{1 \unlhd i \unlhd m} x_{i j}} \quad\left(i=1,2 \cdots m_{j} j=1,2 \cdots, n\right)
$$

For the reverse index, the formula is:

$$
\mathrm{y}_{i j}=\frac{\max _{1 \leq i \leq m} x_{i j}-x_{i j}}{\max _{1 \unlhd i g m} x_{i j}-\min _{1 \leq i \leq m} x_{i j}} \quad\left(i=1,2 \cdots m_{i j} j=1,2 \cdots, n\right) .
$$

Standardized matrices are available $\mathrm{Y}=\left(y_{i j}\right)_{m \times n} \circ$

3. Calculate the $\mathrm{j}^{\text {th }}$ index under the $\mathrm{i}^{\text {th }}$ evaluation value of the proportion $p_{\mathrm{ij}}$

The formula is: $\quad p_{i j}=\frac{x_{i j}}{\sum_{i=1}^{m 2} x_{i j}}$.

4. Calculate the $\mathrm{j}^{\text {th }}$ index of the information entropy $e_{j}$

The formula is: $\quad e_{j}=-k \sum_{i=1}^{m} p_{i j} \ln p_{i j}(k=1 / \ln m)$.

5. Calculate the $\mathrm{j}^{\text {th }}$ index of the entropy weight $w_{j}$

The formula is: $\quad w_{j}=\frac{\left(1-v_{j}\right)}{\sum_{j=1}^{n}\left(1-v_{j}\right)}$.

Among them: $0 \leq w_{j} \leq 1, \sum_{j=1}^{n} w_{j}=1$ 


\section{Value Engineering Evaluation Model set up}

The role of value engineering is to optimize the construction project (or product) by looking for the optimal function and cost ratio (value) of the construction project (or product) ${ }^{[4]}$. Value engineering refers to the collaboration between of optimal function and cost of the object that is being studied, analyzing and innovating. The thinking method and management techniques are aiming to improve the value of the studying object which can be expressed as $\mathrm{V}=F / \mathrm{C}$. where:

$\mathrm{V}$ - The value of the study object (It is mainly reflected on the degree of matching the function and cost of the study object).

F - The function of the study object (It refers to the object meeting a certain needs of a property that are specific to performance, capability or utility). In the tender evaluation model, the corresponding in the construction unit, the bid unit, and excluding quotation are required.

C - Cost (It refers to the study of the life cycle cost that the cost of life period is required for full cost). In the tender evaluation model, it corresponds to the bid of the tender unit.

If the value of a product or operation is higher, the degree of resource utilization is better, but if its value is lower, it indicates that its resources are not being used effectively, so it should be managed and improved. Owners through the tender can select the contract unit. Its essence is through this competitive way to pick a higher quality reputation up, which the owner can reliably to achieve the necessary functions of the project and it can find out the tender who offers lower contract unit. The principle of value engineering is precisely a set of technical scientific with economic analysis method to solve the problem, so it can use the reasonable scientific of bidding evaluation model. The specific process is as below:

1. To determine the studying factors

One bid can or cannot success is based on the significant impact on the key factor that is called "evaluation process" which its value is used to analysis object.

2. Functional analysis of the studying factors

According to the current bidding system, the main factors considering in the bidding evaluation process should be the factors that are necessary for the bidding system to think about, such as the construction period, the project quality, the quality of the main material usage, the quality performance, the construction experience, the construction plan, the environmental protection measures and so on.

3. Functional evaluation of the studying factors

The functional analysis above is shown that the quantitative bidding factors have been evaluated equally and every weight of the indicators rising above shows the method to make entropy weight $\left(w_{j}\right)$. The specific method is shown in Table 1.

Comprehensive evaluation index $P_{i}=A w_{1}+B w_{2}+C w_{3}+D w_{4}+E w_{5}+F w_{6}$. 
Table 1: Functional Analysis Table

\begin{tabular}{|c|c|c|c|c|}
\hline $\mathrm{N}^{\mathrm{o}}$ & Function & Quantitative indicators & Calculation formula & $\begin{array}{l}\text { Weights } \\
\left(w_{j}\right)\end{array}$ \\
\hline 1 & Project duration & $\begin{array}{l}\text { Shortening the duration } \\
\text { of construction }\end{array}$ & $\frac{\text { Ease time limit-Tender duration }}{\text { Base time limit }} \times 100 \%$ & $w_{1}$ \\
\hline 2 & $\begin{array}{l}\text { The amount of } \\
\text { the main } \\
\text { material }\end{array}$ & $\begin{array}{l}\text { Main material savings } \\
\text { rate }\end{array}$ & $\frac{\text { Base dosage-Bid amourt }}{\text { Base dosage }} \times 100 \%$ & $w_{2}$ \\
\hline 3 & $\begin{array}{l}\text { Quality } \\
\text { performance }\end{array}$ & $\begin{array}{l}\text { Excellent engineering } \\
\text { rate } \\
\text { (Nearly } 5 \text { years) }\end{array}$ & $\frac{\text { Arceptance projert exrellent number (area) }}{\text { Nurnber of ountracted projerts (imrea) }} \times 100 \%$ & $w_{3}$ \\
\hline 4 & $\begin{array}{l}\text { Construction } \\
\text { experience }\end{array}$ & $\begin{array}{l}\text { Nearly } 5 \text { years contract } \\
\text { similar } \\
\text { Engineering experience } \\
\text { rate }\end{array}$ & $\frac{\text { Contracted similar number of projecta (ares) }}{M} \times 100 \%$ & $w_{4}$ \\
\hline 5 & $\begin{array}{l}\text { Construction } \\
\text { plan }\end{array}$ & By the evaluation of experts & s to give the average score & $w_{G}$ \\
\hline 6 & $\begin{array}{l}\text { Environmental } \\
\text { protection } \\
\text { measures }\end{array}$ & By the evaluation of experts & $\mathrm{s}$ to give the average score & $w_{\epsilon}$ \\
\hline
\end{tabular}

Note: 1.M is a constant determined by the relevant experts; 2 . The experts scoring give up to ten for taking the very system. It is divided into good ( $8 \sim 10$ points), general ( 6 to 7 points), poor $(1 \sim 5$ points). The averages of the units are divided by 10 as its program where the evaluation of the value is measured.

4. The preferred scheme

For each bid unit, the formula $\mathrm{V}=F / C$. is used to examine the size of its coefficient value. This specific method is passed through from the calculation of functional coefficient and the cost factor, and then carrying out the calculation of coefficient value. If the coefficient value is bigger, the whole inner-quality of contract unit is higher, and it can use to compare for finding out a lower price contract that can make the choice among them:

The functional coefficient $=$ Each unit score $\div$ The sum of each unit score.

Cost factor $=$ Each units tender offer $\div$ The sum of each unit tender offer.

Each unit score $=\sum_{i=1}^{6}$ Quantitative indicators $i \times w_{i} \times 100$ 


\section{Project sample}

A certain construction unit organizes a project tender which is starting cost 15 million Yuan, and the base period of construction is 18 months. The amount of the base material using is 6 million Yuan. Base on the submitting bid document which has examined with qualification pattern, the expert have chosen four bid documents to analyze. The basis of four bidder information are shown in table 2, and the indicator data of the first five information factors are taken from submitting tender units, and the last two qualitative data are taken from the expert.

Table 2: Tender Offer Basic Information Table

\begin{tabular}{|c|c|c|c|c|c|c|c|c|}
\hline Bidders & $\begin{array}{l}\text { Quotes } \\
\text { (ten } \\
\text { thousand } \\
¥ \text { ) }\end{array}$ & $\begin{array}{l}\text { Project } \\
\text { Duration } \\
\text { (month) }\end{array}$ & $\begin{array}{l}\text { The amount } \\
\text { of the main } \\
\text { material } \\
\text { (ten } \\
\text { thousand } \\
¥ \text { ) }\end{array}$ & $\begin{array}{l}\text { Quality } \\
\text { performance }\end{array}$ & $\begin{array}{l}\text { Construction } \\
\text { experience }\end{array}$ & $\begin{array}{l}\text { Construction } \\
\text { plan }\end{array}$ & $\begin{array}{l}\text { Environmental } \\
\text { protection } \\
\text { measures }\end{array}$ & $\begin{array}{l}\text { cost } \\
\text { coefficient }\end{array}$ \\
\hline $1^{\text {st }}$ & 1490 & 17 & 590 & $50 \%$ & $60 \%$ & 0.6 & 0.8 & 0.2011 \\
\hline $2^{\text {nd }}$ & 1520 & 16 & 620 & $30 \%$ & $40 \%$ & 0.7 & 0.7 & 0.2051 \\
\hline $3^{\text {rd }}$ & 1420 & 20 & 575 & $55 \%$ & $70 \%$ & 0.5 & 0.4 & 0.1916 \\
\hline $4^{\text {th }}$ & 1480 & 18 & 580 & $45 \%$ & $55 \%$ & 0.8 & 0.5 & 0.1997 \\
\hline
\end{tabular}

According to the basic data in Table 2, and base on the formula (1), (2) which handling standardized, the entropy method is calculated by the formula (3), (4), (5) which can be obtained every index of the entropy weight, so the available weights of the indicators are shown in Table 3.

Table 3: Information Entropy, Entropy Weight and Weight Scores of Each Evaluation Value

\begin{tabular}{lllllll}
\hline & $\begin{array}{l}\text { Project } \\
\text { Duration }\end{array}$ & $\begin{array}{l}\text { The amount } \\
\text { of the main } \\
\text { material }\end{array}$ & $\begin{array}{l}\text { Quality } \\
\text { performance }\end{array}$ & $\begin{array}{l}\text { Construction } \\
\text { experience }\end{array}$ & $\begin{array}{l}\text { Construction } \\
\text { plan }\end{array}$ & $\begin{array}{l}\text { Environmental } \\
\text { protection } \\
\text { measures }\end{array}$ \\
\hline $\begin{array}{l}\text { Information } \\
\text { entropy }\end{array}$ & 0.6894 & 0.5701 & 0.6494 & 0.7177 & 0.7296 & 0.7028 \\
$\begin{array}{l}\text { Entropy } \\
\text { weight }\end{array}$ & 0.1600 & 0.2215 & 0.1806 & 0.1454 & 0.1393 & 0.1531 \\
$\begin{array}{l}\text { Weight } \\
\text { score }\end{array}$ & 16.00 & 22.15 & 18.06 & 14.54 & 13.93 & 15.31 \\
\hline
\end{tabular}

According to the basic data in Table 2 and Table 3, the weight of the index can be obtained by the total score of the tender unit and it can be obtained from the functional coefficient of the unit. The specific data is shown in Table 4. 
Table 4: Functional Analysis Table

\begin{tabular}{|c|c|c|c|c|c|c|c|c|c|c|c|c|c|c|}
\hline \multirow[t]{2}{*}{ unit } & \multicolumn{2}{|c|}{$\begin{array}{l}\text { Project } \\
\text { Duration }\end{array}$} & \multicolumn{2}{|c|}{$\begin{array}{l}\text { The amount } \\
\text { of the main } \\
\text { material }\end{array}$} & \multicolumn{2}{|c|}{$\begin{array}{l}\text { Quality } \\
\text { performance }\end{array}$} & \multicolumn{2}{|c|}{$\begin{array}{l}\text { Construction } \\
\text { experience }\end{array}$} & \multicolumn{2}{|c|}{$\begin{array}{l}\text { Construction } \\
\text { plan }\end{array}$} & \multicolumn{2}{|c|}{$\begin{array}{l}\text { Environmental } \\
\text { protection } \\
\text { measures }\end{array}$} & \multirow[t]{2}{*}{$\begin{array}{l}\text { Total } \\
\text { score }\end{array}$} & \multirow[t]{2}{*}{$\begin{array}{l}\text { Functional } \\
\text { coefficient }\end{array}$} \\
\hline & index & Score & index & Score & index & Score & index & Score & index & Score & index & Score & & \\
\hline $1^{\text {st }}$ & 0.06 & 0.89 & 0.02 & 0.37 & $50 \%$ & 9.03 & $60 \%$ & 8.73 & 0.6 & 8.36 & 0.8 & 12.25 & 39.62 & 0.2822 \\
\hline $2^{\text {nd }}$ & 0.11 & 1.78 & -0.03 & -0.74 & $30 \%$ & 5.42 & $40 \%$ & 5.82 & 0.7 & 9.75 & 0.7 & 10.72 & 32.75 & 0.2333 \\
\hline $3^{\text {rd }}$ & -0.11 & -1.78 & 0.04 & 0.92 & $55 \%$ & 9.93 & $70 \%$ & 10.18 & 0.5 & 6.97 & 0.4 & 6.12 & 32.35 & 0.2304 \\
\hline $4^{\text {th }}$ & 0.00 & 0.00 & 0.03 & 0.74 & $45 \%$ & 8.13 & $55 \%$ & 8.00 & 0.8 & 11.15 & 0.5 & 7.66 & 35.67 & 0.2541 \\
\hline
\end{tabular}

Based on the previously obtained functional coefficients and cost factors, the principle of value engineering can be used to obtain the value coefficient of each bidding unit, and then the winning unit can be selected according to the size of its value coefficient which has been shown in table 5 .

Table 5: Value Engineering Calculation Table

\begin{tabular}{lllll}
\hline Bidders & $\begin{array}{l}\text { Functional } \\
\text { coefficient }\end{array}$ & Cost coefficient & Value coefficient & Preferred units \\
\hline $1^{\text {st }}$ & 0.2822 & 0.2011 & 1.4037 & $\mathrm{P}$ \\
$2^{\text {nd }}$ & 0.2333 & 0.2051 & 1.1371 & \\
$3^{\text {rd }}$ & 0.2304 & 0.1916 & 1.2025 & \\
$4^{\text {th }}$ & 0.2541 & 0.1997 & 1.2720 & \\
\hline
\end{tabular}

\section{Conclusion}

Entropy weight method and value engineering theory are the more mature theories, which can be applied to the process of bidding evaluation. The whole calculation process is simple and clear, and the basic data is based on their own data, so its calculation result is objectivity.

\section{Acknowledgements}

I would like to say thankful to my supervisor Professor Bao Xue Ying who always encourages me to complete this paper. She always offers me good advice and gives data for me to do this journal. Moreover, I would like to say a million thanks to all the friends who encourage me and give me the good advice.

\section{References}

[1] Professor Wang Zhuo Fu, Bid Evaluation Model of Construction Project Based on Entropy Weight Weighting Method, Research Study of Science and Technology Management, 2010 
[2] Professor Wang En Mao, The Use of Value Engineering Optimize Contractors, Infrastructure Optimization, 1994.4

[3] Zhu Sai Jing, Bid Evaluation Model of Construction Project Based on Information Entropy and Gray Relational Analysis, Journal of Fujian Institute of Engineering, 2012.12

[4] Wang Dao Ping, Wang Xu, Weight Selection of Steel Enterprise for Finding Green Supplier Based on AHP / Entropy Method for Research Study[J], Soft Science, 2012(8): p.117-120. 